Водные биоресурсы и среда обитания 2021, том 4, номер 4, с. 36-43

http://journal.azniirkh.ru, www.azniirkh.ru doi: 10.47921/2619-1024_2021_4_4_36 ISSN 2618-8147 print, ISSN 2619-1024 online

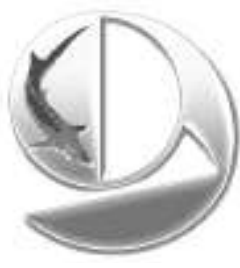

Aquatic Bioresources \& Environment

2021, vol. 4, no. 4, pp. 36-43

http://journal.azniirkh.ru, www.azniirkh.ru

doi: 10.47921/2619-1024_2021_4_4_36

ISSN 2618-8147 print, ISSN 2619-1024 online

\title{
NEW DATA ON FINDING OF ALIEN PRAWN MACROBRACHIUM NIPPONENSE (DECAPODA, PALAEMONIDAE) IN THE DON RIVER (AZOV SEA BASIN)
}

\author{
(C) 2021 L. A. Zhivoglyadova ${ }^{1}$, N. A. Nebesikhina ${ }^{1}$, N. S. Elfimova ${ }^{1}$, D. F. Afanasyev ${ }^{1,2}$ \\ ${ }^{1}$ Russian Federal Research Institute of Fisheries and Oceanography (FSBSI “VNIRO”), \\ Azov-Black Sea Branch of the FSBSI “VNIRO” ("AzNIIRKH”), Rostov-on-Don 344002, Russia \\ ${ }^{2}$ Don State Technical University, Rostov-on-Don 344000, Russia \\ E-mail: zhivoglyadova_l_a@azniirkh.ru
}

\begin{abstract}
For the first time, a freshwater prawn of the genus Macrobrachium Spence Bate, 1868, earlier unknown for the basin of the Azov Sea, was recorded in the lower reaches of the Don River in September, 2019. Based on their morphological characteristics, the found specimens were identified as M. nipponense (De Haan, 1849). This work presents the results of genetic analysis confirming the species status of the prawn, and also reports on new discovery and spreading of this species in the Don River. Oriental river prawn $M$. nipponense is a subtropical species, in its natural range widespread in Southeast Asia. Since the middle of the 1960s, this species is rapidly expanding its range in Eurasia. In a temperate climatic zone within the area of the former USSR, this thermophilic species was introduced in cooling ponds of thermal power plants (TPP). Acclimatization of $M$. nipponense was carried out as a part of warm-water aquaculture in order to improve the food supply of fish and enrich the fauna of TPP cooling ponds. This paper summarizes the available information about the formation of stable populations of $M$. nipponense within the area of the former USSR countries, as well as an assessment of the risks of invasion in the Don River.
\end{abstract}

Keywords: Crustacea, freshwater prawn, alien species, warm-water aquaculture

\section{НОВЫЕ ДАННЫЕ ОБ ОБНАРУЖЕНИИ ЧУЖЕРОДНОЙ КРЕВЕТКИ MACROBRACHIUM NIPPONENSE (DECAPODA, PALAEMONIDAE) В Р. ДОН (БАССЕЙН АЗОВСКОГО МОРЯ)}

\author{
Л. А. Живоглядова ${ }^{1}$, Н. А. Небесихина ${ }^{1}$, Н. С. Елфимова ${ }^{1}$, Д. Ф. Афанасьев ${ }^{1,2}$
}

${ }^{1}$ Всероссийский научно-исследовательский институт рыбного хозяйства и океанографии (ФГБНУ «ВНИРО»), Азово-Черноморский филиал ФГБНУ «ВНИРО» («АзНИИРХ»), Ростов-на-Дону 344002, Россия

${ }^{2}$ Донской государственный технический университет, Ростов-на-Дону 344000, Россия

E-mail: zhivoglyadova_l_a@azniirkh.ru 


\begin{abstract}
Аннотация. Ранее не известные для бассейна Азовского моря пресноводные креветки рода Macrobrachium Spence Bate, 1868 были впервые зарегистрированы в нижнем течении р. Дон в сентябре 2019 г. По морфологическим признакам найденные экземпляры были идентифицированы как M. nipponense (De Haan, 1849). В данной работе приведены результаты генетического анализа, подтверждающего видовой статус креветок, а также сообщается о повторной регистрации вида в p. Дон. Восточная речная креветка M. nipponense - субтропический вид, в естественном ареале широко распространенный в Юго-Восточной Азии. Примерно с середины 1960-х гг. вид стремительно расширяет свой ареал в Евразии. В умеренном климате на территории стран бывшего Союза ССР этот теплолюбивый вид креветок был интродуцирован в водоемы-охладители тепловых электростанций. Акклиматизацию M. nipponense проводили в рамках развития тепловодного направления аквакультуры с целью улучшения кормовой базы рыб и обогащения фауны водоемов-охладителей. В работе обобщаются имеющиеся в доступной литературе сведения о формировании M. nipponense устойчивых популяций на территории стран бывшего Союза ССР, а также дается оценка рисков инвазии в р. Дон.
\end{abstract}

Ключевые слова: ракообразные, пресноводная креветка, чужеродный вид, тепловодная аквакультура

\section{INTRODUCTION}

Oriental river prawn Macrobrachium nipponense (De Haan, 1849) in its native range is widespread in the countries of Southeast Asia, including Japan, China, Korea, Vietnam, Myanmar, and Taiwan [1-4]. In its natural range in Russia, M. nipponense (=Palaemon asper Stimpson, 1860) is recorded in the Lake Khanka on the border with China [5].

Oriental river prawn is a popular aquaculture target. This species ranks the $2^{\text {nd }}$ in the world after the giant river prawn Macrobrachium rosenbergii (de Man, 1879) in terms of its production [6]. According to the FAO, aquaculture farms produce up to 250 thousand tons of marketable prawns annually [7]. The main producer is China, which accounts for most of the total production.

The first prawns were introduced to fish farms in the countries of the former Soviet Union by chance at their larval stage with fish. In the early 1960s, the prawn M. nipponense was introduced with juvenile grass carp Ctenopharyngodon idella (Valenciennes, 1844) into the cooling pond of the hydroelectric power plant in the Moscow Region, where it successfully acclimatized and formed a stable population [8]. Around the same years, this prawn was brought to one of the largest farms of Uzbekistan - the Akkurgan fish farm [9].

Successful naturalization of this thermophilic subtropical species in reservoirs supplied with warm water made it possible to assess the high potential of the oriental river prawn as a target for warm-water aquaculture [9]. Since the late 1960s, this prawn has been purposefully brought into the cooling ponds of the hydroelectric power plants. In 1967, the prawn was introduced into the fish farm of the Zainsk Reservoir (the Republic of Tatarstan, Russia), where it was supplied along with juveniles of grass carp and silver carp Hypophthalmichthys molitrix (Valenciennes, 1844) [10]. In 1982, a large batch of M. nipponense (1.5 thousand individuals) was brought to the cooling pond of the Berezovskaya Hydroelectric Power Plant (Belarus) in order to develop biotechnical methods for prawn cultivation [8]. By 1985, this population had reached 2 million individuals [11], which made it possible to actively develop this area of aquaculture and use the formed population for transfer into other water bodies of the USSR [9].

In 1986, this prawn was brought from the cooling reservoir of the Berezovskaya Hydroelectric Power Plant to the Kuchurgan Estuary (the cooling reservoir of the Moldavskaya Hydroelectric Power Plant (Moldova)) [12, 13]. It is also known of the introduction of $M$. nipponense into the cooling ponds of Primorskaya Hydroelectric Power Plant, Ryazan Hydroelectric Power Plant, Kursk, Smolensk and Kalininsk Nuclear Power Plants (Russia) [9, 14].

The purpose of these large-scale acclimatization measures, which were carried out throughout the country, was to increase the efficiency of using heated waters, improve the food supply for fish, and enrich the fauna of cooling ponds [15]. It was assumed that the acclimatization of $M$. nipponense in reservoirs supplied with warm water would not lead to an uncontrolled spread of the species, since under natural conditions of temperate latitudes the species would not be able to reproduce effectively $[10,11]$.

However, the materials of recent years have shown that this species is actively spreading not only in the countries of Central and Southeast Asia [16-18] under favourable conditions for reproduction in terms of temperature, but also in the northern edge of its range, 
where M. nipponense was previously recorded only in zones of anomalous temperatures [8, 13, 19].

In the Azov Sea Basin, the first two specimens of M. nipponense were found in 2019 near a nameless island on the Don River below the village Arpachin [20]. The new finding of the prawn, discussed in this article, indicates the continuation of the expansion of this species. This work reports on the repeated finding of $M$. nipponense in this water body and presents the results of genetic analysis of this prawn. It should be noted that the genus Macrobrachium Spence Bate, 1868 is rather difficult for identification. Its taxonomy is based mainly on the morphological characters of sexually mature males $[4,5,9]$. Identification of juveniles and females is sometimes difficult, and in some cases is not possible, therefore, the diagnosis of the species by morphological criteria is recommended to be confirmed by genetic studies $[4,21]$.

Thus, the main goal of this work was to clarify the species diagnosis of this prawn, as well as to present new data on the occurrence of this species in the Don River Basin.

\section{MATERIALS AND METHODS}

In October 2020, several prawn specimens were caught by fishermen in the delta of the Don River in the Mokraya Kalancha Channel (Fig. 1). Two specimens were transferred to the Laboratory of Hydrobiology of the Azov-Black Sea Branch of the Russian Federal
Research Institute of Fisheries and Oceanography (Rostov-on-Don).

The prawns were measured using a caliper with an accuracy of up to $0.1 \mathrm{~mm}$ with respect to three parameters: total body length (from the rostrum end to the telson end), standard length (from the posterior margin of the eye orbit to the telson end), and carapace length (from the posterior margin of the eye orbit to the middle of the dorsal part of the posterior margin of the carapace) [22]; they were weighed on a Shimadzu AX-120 electronic balance with an accuracy of $0.001 \mathrm{~g}$ after their preliminary drying on filter paper.

Genomic analysis. The genomic DNA was isolated from the muscle tissues of prawns by the column absorption method (PALL) [23]. The DNA concentration was determined with a Max-Life H100 fluorimeter (MVM-Diagnostics LLC, Russia) using dsDNA-500 kit. The nucleotide sequence of the COI gene was determined and analyzed using universal primers: LCO 1490 (5'-ggtcaacaaatcataaagatattgg-3') and HC02198 (5'-taaacttcagggtgaccaaaaaatca-3') [24]. The polymerase chain reaction (PCR reaction) was carried out at a total volume of $15 \mu \mathrm{L}$ : $5 \mu \mathrm{L}$ of $2.5 \times$ reaction mixture for PCR-RV (NPF Syntol LLC), 10 pmol of each primer, and 20 ng of DNA. PCR was carried out in a T100 thermal cycler (Bio-Rad) according to the following scheme: preliminary DNA denaturation at $95{ }^{\circ} \mathrm{C}$ for $10 \mathrm{~min}$; synthesis of PCR products, 30 cycles, melting at $94{ }^{\circ} \mathrm{C}(20 \mathrm{~s})$, primer annealing

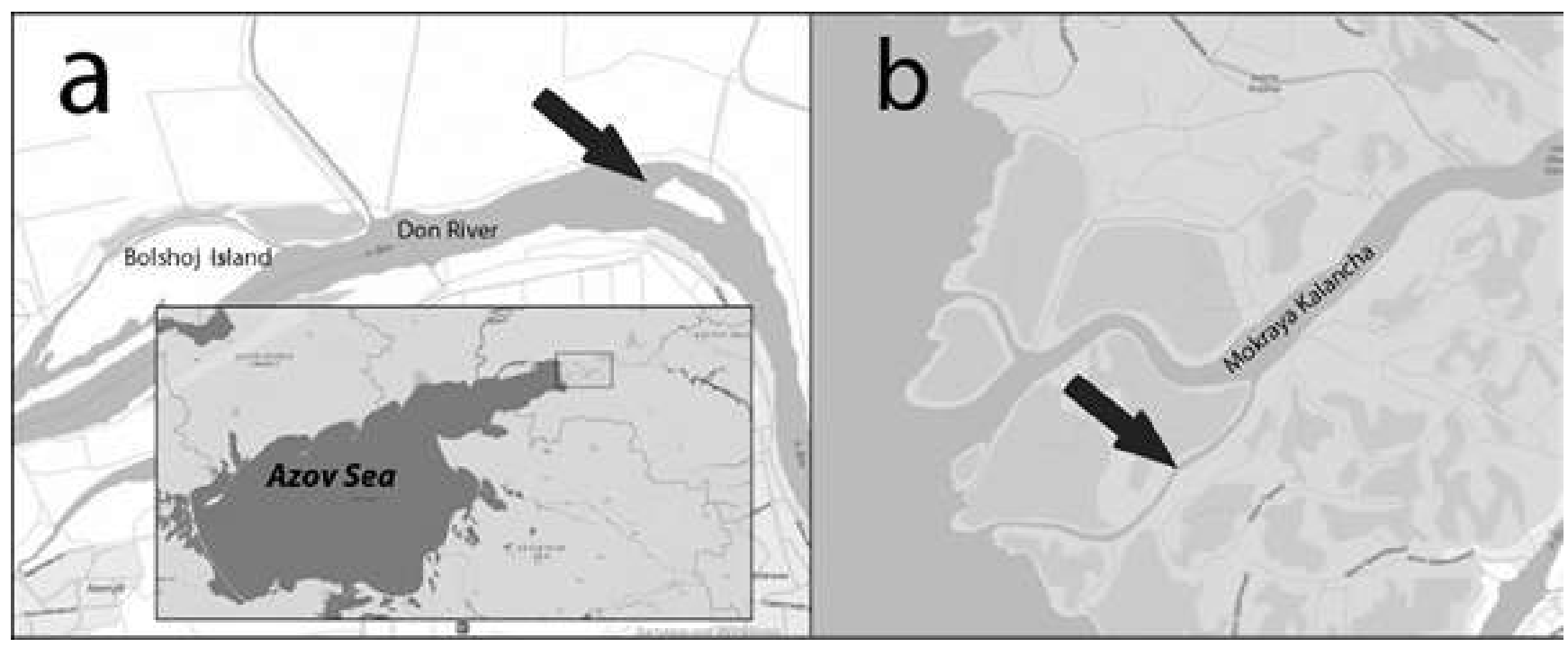

Fig. 1. Map of the locations (indicated by arrow) of first (a) and second (b) findings of M. nipponense in the Don River Рис. 1. Карта с указанием мест (обозначены стрелками) первой (а) и повторной (b) находки M. nipponense в p. Дон 
at $48{ }^{\circ} \mathrm{C}(40 \mathrm{~s})$, DNA synthesis at $72{ }^{\circ} \mathrm{C}(60 \mathrm{~s})$; final building of chains at $72{ }^{\circ} \mathrm{C}, 10 \mathrm{~min}$. The result of amplification was tested by electrophoresis in $1.8 \%$ agarose gel stained with ethidium bromide. The COI gene of mitochondrial DNA was sequenced using the same primers in both directions with a Nanofor 05 sequencing device (EZAN, Russian Academy of Sciences) with the BRILLIANT DYE ${ }^{\mathrm{TM}}$ Terminator Kit (v. 3.1) (NimaGen, Netherlands).

The obtained primary data were processed in the "Analysis" software program (SINTOL, Russia), followed by the analysis and alignment of the sequences in the Chromas Pro software package [25]. The homologous nucleotide sequences were determined by the COI gene using the BLAST software program in the GenBank [26] and BOLD (Barcode of Life Database) genetic databases [27]. The phylogenetic analysis used the COI sequences presented in the studies of M. nipponense: KY977498.1-KY977502.1, KY977505.1 [28], MK412772.1 [4], DQ656415 [21]. The degree of proximity was analyzed in the MEGA5 software package [29] by the maximum parsimony (MP), maximum likelihood (ML), and neighborjoining (NJ) methods according to the TamuraNei model [30]. The bootstrap method using 1000 pseudoreplications was used as a statistical test. The phylogenetic trees constructed by different methods of analysis are topologically very similar; below, the article describes only the tree constructed by the neighbor-joining (NJ) method.

\section{RESULTS AND DISCUSSION}

Both specimens caught in October, 2020 were identified as females of M. nipponense (Decapoda: Palaemonidae) [5]. The largest prawn (Fig. 2) had the total body length $55.5 \mathrm{~mm}$, their standard length was $46.2 \mathrm{~mm}$, carapace length was $12.5 \mathrm{~mm}$, weight was $1.705 \mathrm{~g}$. The second specimen had similar parameters: $48.9 \mathrm{~mm}, 40.0 \mathrm{~mm}, 11.2 \mathrm{~mm}$, and $1.084 \mathrm{~g}$, respectively. The specimens found were compared with the samples obtained earlier, and also compared with the diagnosis of the species [18], which made it possible to identify these prawns as M. nipponense.

Brief description of the species. The rostrum is almost straight, as long or slightly longer than scaphocerites. Its upper margin is armed with 10-12 teeth, including two or three placed posterior to the orbital margin (Fig. 2b). The distance between the penultimate and last teeth is about two times greater than between the previous ones. The lower margin of rostrum is strongly convex, armed with two to three teeth. Setae of the external margin of the rostrum are plume-like, located in one row in the dorsal part and in two rows in the ventral part. Antennules are triramose; the short branch of the external flagellum is approximately $15-20 \%$ adherent with the long branch.

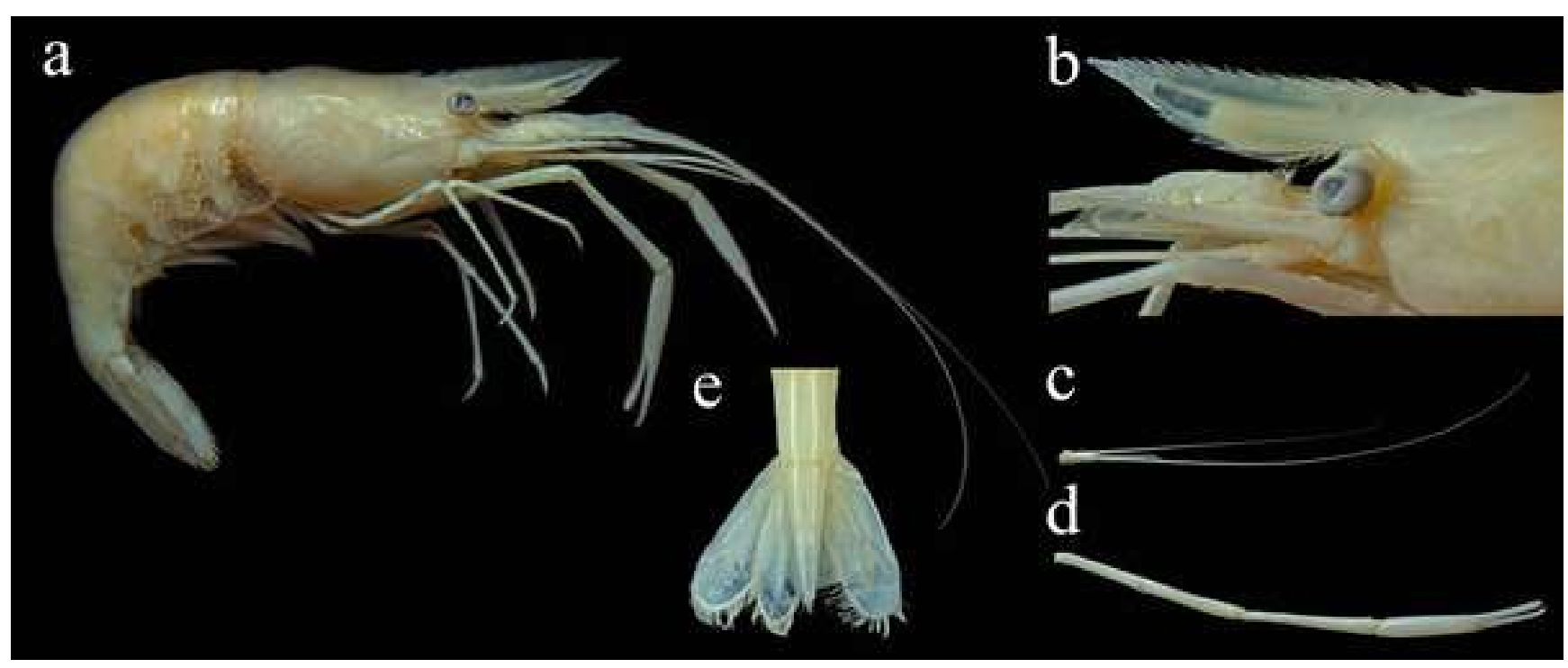

Fig. 2. Prawn M. nipponense (female) from the Don River: (a) general view, (b) rostrum shape, (c) antennules, (d) second pereopod, (e) telson

Рис. 2. Креветка M. nipponense (самка), найденная в р. Дон: (а) общий вид, (b) форма рострума, (c) антеннулы, (d) второй переопод, (е) тельсон 
Antennal scale $0.6-0.7$ times as long as the carapace, 2.4-2.7 times as long as wide. Hepatic spine is of almost the same size as that of antennal one, located posterior to it and slightly lower. The sixth abdominal somite is 1.4-1.7 times as long as the fifth segment, the preanal carina unpronounced. The telson is sub-triangular, moderately acute (Fig. 2e), 1.4-1.5 times as long as the sixth abdominal somite. In addition to the subterminal spines, the telson has two pairs of dorsolateral spines, the first pair of which is in the middle of it. Exopodite of the uropods is slightly longer than endopodite; mobile spine of the uropodial diaeresis is at the same level as the lateral margin or slightly protruding beyond it. The second pereopods are significantly (almost 2 times) longer than the other ones, covered with spinules and sparse setae; the pincer is with bundles of setae. In males (14.3 mm carapace length), the second pereopods reach 0.5 of the body length.

It differs from the diagnosis of the species [18] mainly by the shorter length of the second pereiopod. The latter is probably determined by the allometry of limb growth; we studied relatively small specimens with a carapace length of $14.3 \mathrm{~mm}$.

The resulting nucleotide sequence with a length of $632 \mathrm{bp}$ corresponds to position 37-699 of the cytochrome oxidase subunit I gene from complete genome of mtDNA of $M$. nipponense [31].

Comparison of the sequences of the COI gene region revealed that the nucleotide composition of specimen $M$. nipponense caught in the Don River differed by less than $1 \%$ with other specimens of this species, which corresponds to the intraspecific polymorphism (Fig. 3). The phylogenetic tree has two clearly pronounced clades with a high bootstrap support level (>90 \%). Prawn M. nipponense from the Don River belongs to the same clade as samples from Iran, Iraq, and south-eastern China (Fig. 3).

At present, several stable populations of M. nipponense are known to have formed under conditions of temperate zones within the former Soviet Union countries. In the Zainsk Reservoir, the population of $M$. nipponense has been successfully existing for over 40 years. Here, the quantitative assessment conducted during 20042010 indicated a high-density population, locally reaching 41 ind. $/ \mathrm{m}^{2}$ [10]. A large population of $M$. nipponense lives in the cooling reservoir system of the Berezovskaya Hydroelectric Power Plant. After its decline in quantitative characteristics in
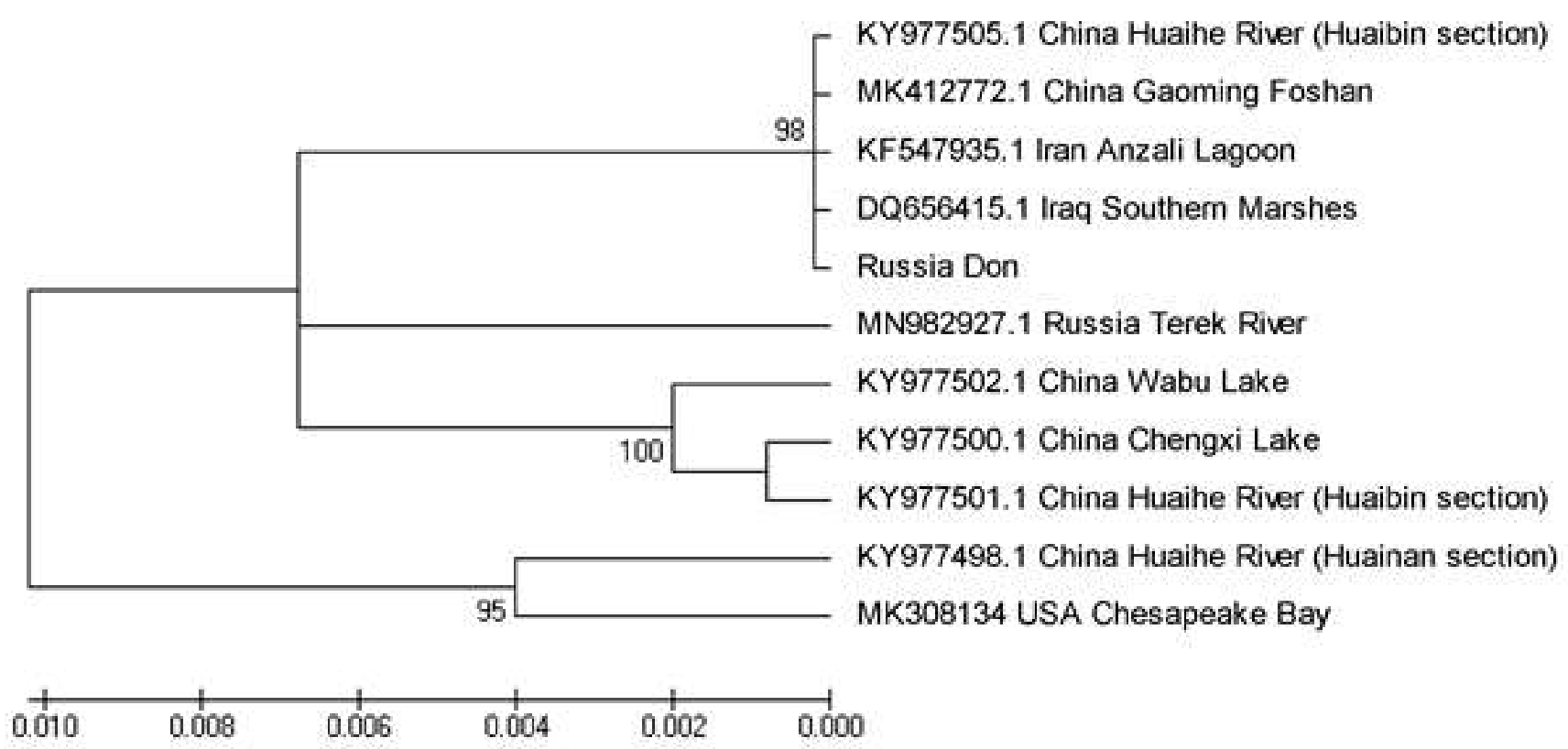

Fig. 3. Phylogenetic tree of representatives of species $M$. nipponense based on the nucleotide sequences of the COI gene. Indices in nodes indicate the bootstrap support values of over $90 \%$ of 1000 replicates. The GenBank inventory number is followed by the name of the country

Fig. 3. Филогенетическое дерево представителей вида M. nipponense, построенное на основании нуклеотидных последовательностей гена COI (I цитохромоксидазы). Числа в узловых точках указывают на значения бутстреп-поддержки, превышающие 90 \% от 1000 реплик. За номером в базе генетических данных GenBank следует название страны 
2003-2007, the population increased its abundance in subsequent years - probably due to a change in the temperature regime in the cooling pond. According to the data obtained in 2014, the number of females reached 28 ind. $/ \mathrm{m}^{2}$, and the number of males was up to 22 ind. $/ \mathrm{m}^{2}$ in some parts of this aquatic system [32]. Another population of oriental river prawn lives in the Kuchurgan Liman [12].

Outside of the influence of thermal waters from power plants, prawns are regularly found in the area of the Kamsky Reach of the Kuybyshev Reservoir [19, 33] and in the lower reaches of the Dniester River. The materials of the recent years show a wide distribution of the oriental river prawn to the Dniester River Basin $[8,12,13]$.

Recently, M. nipponense was found in the lower reaches of the Terek River [34]. Repeated findings of adults and juveniles of oriental river prawn in 20172018 suggest the existence of stable population in the basin of Terek River.

The repeated findings of M. nipponense in the Lower Don River area one year after its first recording, as well as the presence of females with eggs on the pleopods, suggest the formation of another invader population under more inclement climatic conditions than the ones assumed to be suitable for this thermophilic species.

In the lower reaches of the Don River, this thermophilic invader species finds optimal conditions for its development, mainly in the zones of thermal waters, which it uses as refugia. The closest water body of such kind is the thermal canal of the Novocherkassk Hydroelectric Power Plant (HPP). Previously, some thermophilic species of invasive fauna have been already recorded here: the bivalve mollusc Corbicula fluminea (O.F. Müller, 1774) [35] and the channel catfish Ictalurus punctatus (Rafinesque, 1818) [36]. However, until present, M. nipponense has not been found in the thermal canal of the Novocherkassk HPP.

\section{CONCLUSION}

Genetic analysis of the samples collected in the Don River confirmed the diagnosis of this species based on the morphological criteria. The repeated findings of $M$. nipponense indicate the possibility of formation of a large population of this prawn in relatively harsh [37] conditions in the Don River. Such possibility may increase in the future, taking into account the longterm trend of the global warming at the Earth's surface [38] and the corresponding climatic processes in the European part of Russia [39].

\section{ACKNOWLEDGEMENTS}

The authors are grateful to the staff of the Department of State Monitoring of Aquatic Biological Resources and Their Habitat at "AzNIIIRKH" for the materials provided, as well as personally to T.O. Barabashin for his assistance in preparation of this publication.

\section{REFERENCES}

1. Suprunovich A.V., Makarov Yu.N. Kul'tiviruemye bespozvonochnye. Pishchevye bespozvonochnye: Midii, ustritsy, grebeshki, raki, krevetki [Cultivated invertebrates. Food invertebrates: mussels, oysters, scallops, crayfish, shrimps]. Kiev: Naukova Dumka [Scientific Thought], 1990, 261 p. (In Russian).

2. Cai Y., Ng P.K.L. The freshwater palaemonid prawns (Crustacea: Decapoda: Caridea) of Myanmar. Hydrobiologia, 2002, no. 487, pp. 59-83. doi: 10.1023/A:1022991224381.

3. Chen P.C., Shih C.H., Chu T.J., Lee Y.C., Tzeng T.D. Phylogeography and genetic structure of the oriental river prawn Macrobrachium nipponense (Crustacea: Decapoda: Palaemonidae) in East Asia. Public Library of Science One, 2017, vol. 12, no. 3, pp. 1-16. doi: 10.1371/journal.pone.0173490.

4. Zheng X.Z., Chen W.J., Guo Z.L. The genus Macrobrachium (Crustacea, Caridea, Palaemonidae) with the description of a new species from the Zaomu Mountain Forest Park, Guangdong Province, China. ZooKeys, 2019, issue 866, pp. 65-83. doi: 10.3897/ zookeys.866.32708.

5. Opredelitel' presnovodnykh bespozvonochnykh Rossii i sopredel'nykh territoriy. T. 2. Rakoobraznye [Key to freshwater invertebrates of Russia and adjacent lands. Vol. 2. Crustacea]. S.Ya. Tsalolikhin (Ed.). SaintPetersburg: Nauka [Science], 1995, 526 p. (In Russian).

6. Freshwater prawns: biology and farming. M.B. New, W.C. Valenti, J.H. Tidwell, L.R. D’Abramo, M.N. Kutty (Eds.). New York: John Wiley \& Sons, 2009, 560 p.

7. Fishery and aquaculture statistics. Global production by production source 1950-2018. In: FishStatJ. Software for fishery and aquaculture statistical time series. Available at: www.fao.org/fishery/statistics/software/ fishstatj/en (accessed 30.09.2021).

8. Stepanok N.A. Oriental river prawn of the genus Macrobrachium in the lower reach of the Dniester River. Hydrobiological Journal, 2014, vol. 50, no. 4, pp. 110-113. doi: 10.1615/HydrobJ.v50.i4.130.

9. Khmeleva N.N., Giginyak Yu.G., Kulesh V.F. Presnovodnye krevetki [Freshwater prawns]. Moscow: Agropromizdat [Agriculture Industry Publishing House], 1988, 127 p. (In Russian).

10. Leontyev V.V. Lokalizatsiya presnovodnoy krevetki Macrobrachium nipponense (De Haan, 1849) v Zainskom vodokhranilishche [Localization of freshwater 
shrimp Macrobrachium nipponense (De Haan, 1849) in Zainsk Reservoir]. Innovatsii i investitsii [Innovation \& Investment], 2015, no. 3, pp. 232-234. (In Russian).

11. Giginyak Yu.G., Alekhnovich A.V., Kulesh V.F. Rezul'taty introduktsii subtropicheskoy presnovodnoy krevetki Macrobrachium nipponense De Haan v vodoem-okhladitel' Berezovskoy GRES (Belarus') [Results of the introduction of the subtropical freshwater prawn Macrobrachium nipponense De Haan into the cooling pond of the Beryozovskaya SDPP (Belarus)]. In: Tezisy dokladov VII Vserossiyskoy konferentsii po promyslovym bespozvonochnym pamyati B.G. Ivanova (1937-2006) (g. Murmansk, 9-13 oktyabrya 2006 g.) [Abstracts of the $7^{\text {th }}$ AllRussian Conference on commercial invertebrates in memory of B.G. Ivanov (1937-2006) (Murmansk, 9-13 October, 2006)]. Moscow: VNIRO Publ., 2006, pp. 276-277. (In Russian).

12. Shekk P.V., Astafurov Yu.O. Reproduktyvni kharakterystyky introdutsenta - skhidnoyi prisnovodnoyi krevetky (Macrobrachium nipponense De Haan, 1849) — $\mathrm{v}$ ponyzzi Dnistra [Reproductive characteristics of the introduced species - eastern freshwater shrimps (Macrobrachium nipponense De Haan, 1849) in the Lower Dnister River]. Rybogospodars 'ka nauka Ukrayi$n y$ [Fisheries Science of Ukraine], 2019, vol. 50, no. 4, pp. 23-36. doi: 10.15407/fsu2019.04.023. (In Ukrainian).

13. Son M.O., Morhun H., Novitskyi R.O., Sidorovskyi S., Kulyk M., Utevsky S. Occurrence of two exotic decapods, Macrobrachium nipponense (de Haan, 1849) and Procambarus virginalis Lyko, 2017, in Ukrainian waters. Knowledge \& Management of Aquatic Ecosystems, 2020, issue 421, pp. 1-11. doi: 10.1051/kmae/2020032.

14. Borisov R.R. Desyatinogie rakoobraznye (Decapoda) kontinental'nykh vodoemov Severnoy Evrazii [Decapoda fauna of continental waters of Northern Eurasia.] In: Aktual'nye problemy izucheniya rakoobraznykh kontinental'nykh vod: materialy lektsiy i dokladov Mezhdunarodnoy shkoly-konferentsii (p. Borok, 5-9 noyabrya 2012 g.) [Crucial problems of studying crustaceans of continental waters. Proceedings oflectures and reports of the International School-Conference (Borok Settlement, 5-9 November, 2012)]. A.V. Krylov (Ed.). Kostroma: Kostromskiy izdatel'skiy dom [Kostroma Publishing House], 2012, pp. 7-20. (In Russian).

15. Kulesh V.F. Biologicheskie osnovy teplovodnoy akvakul'tury promyslovykh rakoobraznykh : avtoref. dis. dokt. biol. nauk [Biological basics of warm-water aquaculture of commercial crustaceans. Extended abstract of Doctor's (Biology) Thesis]. Minsk: Nauchnoprakticheskiy tsentr Natsional'noy akademii nauk Belarusi po bioresursam [Scientific and Practical Center of the National Academy of Sciences of Belarus for Bioresources] Publ., 2013, 43 p. (In Russian).

16. Mirabdullaev I.M., Niyazov D.S. Chuzherodnye Decapoda (Crustacea) v Uzbekistane [Alien Decapoda (Crustacea) in Uzbekistan.] In: Chuzherodnye vidy $v$
Golarktike (Borok-2) : tezisy dokladov Vtorogo mezhdunarodnogo simpoziuma po izucheniyu invaziynykh vidov (p. Borok, 27 sentyabrya - 1 oktyabrya 2005 g.) [Alien species in Holarctic (Borok-2). Abstracts of the Second International Symposium for the Study of Invasion of Alien Species (Borok Settlement, 27 September - 1 October, 2005)]. Yu.Yu. Dgebuadze, Yu.V. Slynko (Eds.). Rybinsk: Institut biologii vnutrennikh vod im. I.D. Papanina Rossiyskoy akademii nauk [Papanin Institute for Biology of Inland Waters, Russian Academy of Sciences] Publ., Institut problem ekologii i evolyutsii im. A.N. Severtsova Rossiyskoy akademii nauk [A.N. Severtsov Institute of Ecology and Evolution, Russian Academy of Sciences] Publ., 2005, pp. 113-114. (In Russian).

17. De Grave S., Ghane A. The establishment of the oriental river prawn, Macrobrachium nipponense (De Haan, 1849) in Anzali Lagoon, Iran. Aquatic Invasions, 2006, vol. 1, issue 4, pp. 204-208. doi: 10.3391/ai.2006.1.4.2.

18. Hanamura Y., Imai H., Lasasimma O., Souliyamath P., Ito S. Freshwater prawns of the genus Macrobrachium Bate, 1868 (Crustacea, Decapoda, Palaemonidae) from Laos. Zootaxa, 2011, vol. 3025, no. 1, pp. 1-37. doi: 10.11646/zootaxa.3025.1.1.

19. Yakovleva A.V., Yakovlev V.A. Modern fauna and quantitative parameters of invasive invertebrates in zoobenthos of upper reaches of the Kuybyshev Reservoir, Russia. Russian Journal of Biological Invasions, 2010, vol. 1, no. 3, pp. 232-241. doi: 10.1134/S2075111710030161.

20. Zhivoglyadova L.A., Vekhov D.A., Spiridonov V.A., Guskova O.S., Afanasyev D.F. Pervaya nakhodka vostochnoy krevetki Macrobrachium nipponense (De Haan, 1849) v nizhnem techenii reki Don (basseyn Azovskogo morya) [The first finding of the oriental river prawn Macrobrachium nipponense (De Haan, 1849) in the Lower Don River (Azov Sea Basin)]. Vodnye bioresursy $i$ sreda obitaniya [Aquatic Bioresources \& Environment], 2021, vol. 4, no. 1, pp. 2834. doi: 10.47921/2619-1024_2021_4_1_28. (In Russian).

21. Salman S.D., Page T.J., Naser M.D., Yasser A.G. The invasion of Macrobrachium nipponense (De Haan, 1849) (Caridea: Palaemonidae) into the Southern Iraqi Marshes. Aquatic Invasions, 2006, vol. 1, issue 3, pp. 109-115. doi: 10.3391/ai.2006.1.3.2.

22. Nizyaev S.A., Bukin S.D., Klitin A.K., Perveeva E.R., Krutchenko A.A., Abramova E.V. Posobie po izucheniyu promyslovykh rakoobraznykh dal'nevostochnykh morey Rossii [A manual for the study of commercially valuable crustaceans of the Far East Seas of Russia]. Yuzhno-Sakhalinsk: Sakhalinskiy nauchnoissledovatel'skiy institut rybnogo khozyaystva i okeanografii [Sakhalin Research Institute of Fisheries and Oceanography] Publ., 2006, 114 p. (In Russian).

23. Ivanova N.V., deWaard J.R., Hebert P.D.N. An inexpensive, automation-friendly protocol for recovering high-quality DNA. Molecular Ecology 
Notes, 2006, vol. 6, issue 4, pp. 998-1002. doi: 10.1111/j.1471-8286.2006.01428.x.

24. Folmer O., Black M.B., Hoeh W., Lutz R., Vrijenhoek R.C. DNA primers for amplification of mitochondrial cytochrome $c$ oxidase subunit I from diverse metazoan invertebrates. Molecular Marine Biology and Biotechnology, 1994, vol. 3, no. 5, pp. 294-299.

25. Technelysium. DNA sequencing software. Available at: https://technelysium.com.au/wp/ (accessed 30.09.2021).

26. GenBank. Genetic sequence database. Available at: https:/www.ncbi.nlm.nih.gov/genbank/ (accessed 30.09.2021).

27. Ratnasingham S., Hebert P.D.N. BOLD: the Barcode of Life Data System. Molecular Ecology Notes, 2007, vol. 7, no. 3, pp. 355-364. doi: 10.1111/j.14718286.2007.01678.x.

28. Aquaculture in China: success stories and modern trends. J.F. Gui, Q. Tang, Z. Li, J. Liu, S.S. De Silva (Eds.). New York: John Wiley \& Sons, 2018, 416 p.

29. Tamura K., Peterson D., Peterson N., Stecher G., Nei M., Kumar S. MEGA5: molecular evolutionary genetics analysis using Maximum Likelihood, Evolutionary Distance, and Maximum Parsimony methods. Molecular Biology and Evolution, 2011, vol. 28, no. 10, pp. 2731-2739. doi: 10.1093/molbev/ msr121.

30. Tamura K., Nei M. Estimation of the number of nucleotide substitutions in the control region of mitochondrial DNA in humans and chimpanzees. Molecular Biology and Evolution, 1993, vol. 10, no. 3, pp. 512-526. doi: 10.1093/oxfordjournals. molbev.a040023.

31. HQ830201.1. Macrobrachium nipponense mitochondrion, complete genome. In: GenBank. Genetic sequence database. Available at: https://www.ncbi.nlm. nih.gov/nuccore/HQ830201.1 (accessed 30.09.2021).

32. Kulesh V.F., Alekhnovich A.V., Solosnyuk N.V. Razmerno-polovaya struktura i chislennost' populyatsii vostochnoy rechnoy krevetki $\mathrm{v}$ teplom sbrosnom kanale Berezovskoy GRES v kontse vegetatsionnogo sezona [The size and sex structure of the Macrobrachium nipponense (De Haan) shrimp in the warm discharge channel of Bereza Power Plant at the end of the growing season]. Vestsi Belaruskaga dzyarzhaunaga pedagagichnaga universiteta imya Maksima Tanka. Seryya 3. Fizika. Matematyka. Infarmatyka. Biyalogiya.
Geagrafiya [Maxim Tank Belarusian State Pedagogical University (BSPU) Bulletin. Series 3. Physics. Mathematics. Informatics. Biology. Geography], 2015, no. 3 (85), pp. 3-11. (In Russian)

33. Pirogov V.V., Filchakov V.A., Zinchenko T.D., Karpyuk M.I., Edskiy L.B. Novye elementy v sostave bentofauny Volgo-Kamskogo kaskada vodokhranilishch [The new elements in benthic fauna structure of Volga-Kama's cascade reservoirs]. Zoologicheskiy zhurnal [Russian Journal of Zoology], 1990, vol. 69, no. 9, pp. 138-142. (In Russian).

34. Afanasyev D.F., Zhivoglyadova L.A., Nebesikhina N.A., Magomedov M.A., Mutallieva Yu.K., Velibekova B.D., Mirzoyan A.V. Finding of oriental river prawn Macrobrachium nipponense (De Haan, 1849) in the Lower Terek River (Caspian Sea Basin). Russian Journal of Biological Invasions, 2020, vol. 11, no. 3, pp. 191-197. doi: 10.1134/S2075111720030029.

35. Zhivogyadova L.A., Revkov N.K. First records of Corbicula fluminea (O.F. Müller, 1774) (Mollusca: Bivalvia) from the Lower Don. Ecologica Montenegrina, 2018, vol. 17, pp. 46-52. doi: 10.37828/em. 2018.17.6.

36. Luzhnyak V.A., Korneev A.A. Modern ichthyofauna of the Lower Don Basin in conditions of the anthropogenic transformation of its runoff. Journal of Ichthyology, 2006, vol. 46, no. 7, pp. 525-533. doi: 10.1134/ S0032945206070046.

37. Lavajoo F., Amrollahi Biuki N., Khanipour A.A., Mirzajani A., Gutierrez Fruitos J., Akbarzadeh A. Natural diet of Macrobrachium nipponense shrimp from three habitats in Anzali Wetland, Iran. Caspian Journal of Environmental Sciences, 2019, vol. 17, no. 2, pp. 101-111. doi: 10.22124/cjes.2019.3404.

38. Climatic Research Unit (CRU) University of East Anglia. Available at: https://www.uea.ac.uk/groups-andcentres/climatic-research-unit (accessed 30.09.2021).

39. Doklad ob osobennostyakh klimata na territorii Rossiyskoy Federatsii [A report on climate features on the territory of the Russian Federation in 2019]. Moscow: Federal'naya sluzhba po gidrometeorologii i monitoringu okruzhayushchey sredy (Roshydromet) [Russian Federal Service for Hydrometeorology and Environmental Monitoring (Roshydromet)] Publ., 2020, 97 p. (In Russian).

Поступила 01.10.2021

Принята к печати 09.11.2021 